Winter 2004

\title{
From Empire to Globalization . . . and Back? A Post-Colonial View of Transjudicialism
}

Hannah Buxbaum

Indiana University Maurer School of Law, hbuxbaum@indiana.edu

Follow this and additional works at: https://www.repository.law.indiana.edu/ijgls

Part of the International Law Commons

\section{Recommended Citation}

Buxbaum, Hannah (2004) "From Empire to Globalization . . . and Back? A Post-Colonial View of Transjudicialism," Indiana Journal of Global Legal Studies: Vol. 11 : Iss. 1 , Article 8.

Available at: https://www.repository.law.indiana.edu/ijgls/vol11/iss1/8

This Symposium is brought to you for free and open access by the Law School Journals at Digital Repository @ Maurer Law. It has been accepted for inclusion in Indiana Journal of Global Legal Studies by an authorized editor of Digital Repository @ Maurer Law. For more information, please contact rvaughan@indiana.edu.

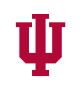

JEROME HALL LAW LIBRARY

INDIANA UNIVERSITY

Maurer School of Law
Blooming ton 


\title{
From Empire to Globalization ... and Back? A Post-Colonial View of Transjudicialism
}

\author{
Hannah L. Buxbaum*
}

From Empire to Globalization: The New Zealand Experience presents a picture of a government at a fascinating historical moment-achieving full status as an independent sovereign, ridding itself of the last vestiges of colonialism, just as the forces of globalization are changing in such dramatic ways what sovereignty means. Looking at this moment, Professor McLean analyzes not globalization as an abstract force, but rather the deep institutional effects that globalization has had on one nation's internal sovereignty. Her examination of such developments as the expanded role of New Zealand's judiciary in interpreting human rights instruments, and the means by which international economic instruments are incorporated into national legislation, reveals the impact of globalization on New Zealand's system of parliamentary sovereignty as well as the restraints that it imposes on the exercise of executive and legislative autonomy in the country. Throughout, her paper exposes ways in which certain elements of globalization echo elements of the country's earlier colonialism.

Much of Professor McLean's paper discusses the particular challenges that globalization presents to the country's judicial system. In New Zealand courts, the influence of the colonial institutions that bound New Zealand to an empire is fading, 'while international law-which will bind New Zealand to the global community - is gaining strength. One aspect of this phenomenon that Professor McLean discusses is the process by which the common law has become "more permeable to human rights and other international law norms." 2 This process is part of a larger process of judicial globalization, and a question her paper raises is what the experience of the judiciary in New Zealand might tell us about judicial globalization more generally-how that experience might be used to test

*Professor of Law and Ira C. Batman Faculty Fellow, Indiana University School of LawBloomington. This is an expanded version of a comment delivered at a symposium on Globalization and the Courts, April 2003, in response to Janet McLean, From Empire to Globalization: The New Zealand Experience, 11 Ind. J. Global Leg. Stud. 161 (2004). I would like to thank Janet McLean and also Wiebke Buxbaum and Larry Helfer for their helpful comments.

1. See the discussion regarding the end of the Privy Council review. Id. at 164-67].

2. Id. at 171 . 
some of the claims that are being made regarding the emergence of a global community of courts. In this comment, I will explore the ways in which the postcolonial view of globalization that she presents exposes the issues of power and status that continue to underpin transjudicialism.

Scholars analyzing the emerging transjudicial community point to a variety of ways in which courts have become more global, including the increase in formal and informal cooperation between courts (and individual judges) in different jurisdictions, rearticulations of the notion of judicial comity in litigation involving private parties, and the development of supranational tribunals. ${ }^{3}$ One of the major pillars supporting this global community is a process that has been described as "constitutional cross-fertilization." "This cross-fertilization develops as national courts around the world look to foreign and international law in adjudicating constitutional issues, particularly in the area of human rights. Thus, the developments that Professor McLean identifies as affecting the internal sovereignty of New Zealand (for instance, the incorporation of international human rights norms into New Zealand's Bill of Rights) ${ }^{5}$ are part of the creation of this external global judicial community.

As observers of this phenomenon point out, the use of foreign or international law in national courts is not entirely new-and, indeed, the example most often pointed to of "old" style cross-fertilization is the role of imperial law in the courts of the colonies. But now, as Anne-Marie Slaughter and others have argued, a different kind of cross-fertilization is developing-in their view, different both as to its processes and as to its motives. The argument is that these differences really do distinguish globalization from empire, marking the ways in which the system of international law supporting conquest and colonization has been replaced by a cosmopolitan, egalitarian system of international law.

3. See, e.g., Reem Bahdi, Globalization of Judgment: Transjudicialism and the Five Faces of International Law in Domestic Courts, 34 Geo. Wash. INT'L L. Rev. 555 (2002); Laurence R. Helfer and Anne-Marie Slaughter, Toward a Theory of Effective Supranational Adjudication, 107 YALE L.J. 273 (1997); Claire L'Heureux-Dubé, The Importance of Dialogue: Globalization and the International Impact of the Rehnquist Court, 34 Tulsa L.J. 15 (1998); Anne-Marie Slaughter, A Typology of Transjudicial Communication, 29 U. Rich. L. Rev. 99 (1994) [hereinafter Typology]; Anne-Marie Slaughter, Judicial Globalization, 40 VA. J. INT'L L. 1103 (2000) [hereinafter Judicial Globalization]; AnneMarie Slaughter, A Global Community of Courts, 44 HaRv. INT'L L.J. 191 (2003) [hereinafter Global Community]; Symposium, Judicialization and Globalization of the Judiciary, 38 Texas INT'L L.J. (Special 2003).

4. See, e.g., Judicial Globalization, supra note 3, at 1104.

5. See McLean, supra note *, at 170-76. 
The process of cross-fertilization across courts today is of course vastly different from what it was in the colonial era. As Professor McLean's paper notes, it was critical that in all parts of the British Empire, the interpretation of the law be "as nearly as possible the same." ${ }^{6}$ Thus, while local custom in each colony might have had a particular formal status, ${ }^{7}$ and while the colonies may have felt themselves to be part of the empire, it is doubtful that there was much of a two-way conversation between the courts of the individual colonies and those of the imperial power in which that law was created. Today, it is suggested, conversations among courts take the form of a dialogue rather than a monologue; they are part of an interactive process rather than one characterized by the segregation of courts that give norms from those that receive them. ${ }^{8}$ Commentators point also to a difference in the way that courts perceive their role in this process: for instance, in distinguishing this new cross-fertilization from older mechanisms of judicial dialogue, Professor Slaughter points to the "self-conscious construction of a global judicial community."

Professor McLean's analysis suggests, however, that participation in this process is experienced quite differently by different courts. The phrase "selfconscious construction of a global judicial community" is a nice one precisely because there are two ways to read self-consciousness in this context. One refers to self-conscious participation in the active sense-that is, the deliberate choice to evaluate the rationales of other courts and also provide one's own rationales as contributions to the developing dialogue. ${ }^{10}$ But another refers to self-consciousness in the sense of an awareness of having to conform to a standard imposed by the leading powers. In this sense, it seems that courts in some countries might view their task not as joining in the creation of a global community, but rather as obtaining the approval of the states that lead the global community. ${ }^{11}$ In the

6. Id. at 165 (quoting Trimble v. Hill, 5 App. Cas. 342, 345 (P.C. 1879)).

7. Id. at $164-65 \& \mathrm{n} .11$.

8. See L'Heureux-Dubé, supra note 3, at 17 (suggesting that a system in which some courts give standards and some receive has been replaced by "cross-pollination and dialogue between jurisdictions," particularly in the area of human rights law).

9. Glabal Community, supra note 3, at 196.

10. Slaughter describes the "deep sense of participation in a common global enterprise of judging." Judicial Globalization, supra note 3, at 1104.

11. See Bahdi, supra note 3, at 557, 590-95 (identifying "concern to avoid negative assessments from the international community" as one of the reasons that judges choose to invoke international law); $f$. Typology, supra note 3, at 134 ("The court of a fledgling democracy, for instance, might look to the opinions of courts in older and more established democracies as a way of binding its country to this existing community of states."). 
Tavita case discussed in Professor McLean's paper, Justice Cooke worried that "legitimate criticism could extend to the New Zealand Courts if they were to accept the argument that [the executive is free to ignore international human rights norms]." In an earlier New Zealand case, too, the court described certain international treaties as representing "goals towards which members of the United Nations are expected to work."13 In such opinions, one hears a certain tone of the court wanting to keep in step with the global community-much, perhaps, as the colonies sought to belong to and be approved by the Commonwealth. ${ }^{14}$ In other courts, by contrast, the judges may experience self-consciousness in neither sense, choosing instead to remain relatively closed to transjudicialism. In the United States Supreme Court, for instance, while some Justices have referred to foreign and international law in their opinions on constitutional issues, ${ }^{15}$ others have resisted that influence quite strongly. ${ }^{16}$

Aside from such differences in judicial mindset, there are also substantial differences in the context in which international norms are used in various cases. ${ }^{17}$ The preamble to New Zealand's Bill of Rights Act 1990, for example,

12. Tavita v. Minister of Immigration [1994] 2 N.Z.L.R. 257, 266, discussed in McLean, supra note $*, 172-74$.

13. Van Gorkom v. Attorney-General, [1977] 1 N.Z.L.R. 535, 543. Similar articulations are found in decisions of other courts in countries including South Africa, Australia, India and Tanzania. See generally Bahdi, supra note 3, at 590-91 (discussing cases from several countries).

14. See McLean, supra note *, at 166-67, 169.

15. See, e.g., Knight v. Florida, 528 U.S. 990,995-98 (1999) (Breyer, J., dissenting); Thompson v. Oklahoma, 487 U.S. 815, 830-31, 851-52 (1988). For examples from the most recent Supreme Court term, see Grutter v. Bollinger, 123 S.Ct. 2325, 2347 (2003) (Ginsburg, J., concurring) (referencing, in the opening of her opinion, the International Convention on the Elimination of All Forms of Racial Discrimination and the Convention on the Elimination of All Forms of Discrimination Against Women) and Lawrence v. Texas, 123 S.Ct. 2472, 2481 (Kennedy, J.) (2003) (citing a decision of the European Court of Human Rights holding laws prohibiting homosexual conduct invalid under the European Convention on Human Rights). See also Justice Scalia's dissent in the latter case, dismissing the majority's references to foreign law as "meaningless" and "dangerous" dicta. Id. at 2495 .

16. See Foster v. Florida, 537 U.S. 990, 991 (2002) (Thomas, J., concurring) (stating that U.S. constitutional jurisprudence should not "impose foreign moods, fads, or fashions on Americans"); see also Printz v. United States, 521 U.S. 898, $921 \mathrm{n} .11$ (1997) (Scalia, J.) (stating that comparative analysis is "inappropriate to the task of interpreting a constitution, though it was of course quite relevant to the task of writing one"). See also L'Heureux-Dubé, supra note 3, at 37-40 (criticizing the Rehnquist Court's general unwillingness to utilize foreign law in its decision making).

17. See generally Bahdi, supra note 3 (analyzing five different reasons that judges choose to utilize international law in the decision-making process); Typology, supra note 3. 
states not only that the statute affirms "human rights and fundamental freedoms in New Zealand," but also that it affirms "New Zealand's commitment to the International Covenant on Civil and Political Rights." 18 Thus, the law expressly indicates that harmonization with international norms is part of the legislative intent, and therefore directs New Zealand courts to consider the jurisprudence interpreting that instrument, wherever it emerges, in interpreting the particular rights protected by the Act. That is of course very different from a situation in which the court is interpreting a domestic constitutional standard that was not itself derived from an international treaty or convention, and therefore reviews decisions of foreign courts merely for information and persuasive arguments, ${ }^{19}$ as some Justices of the United States Supreme Court have done. ${ }^{20}$

All in all, these differences in the process of constitutional cross-fertilization suggest that while the flow of international and foreign law into national courts does not take the form of a monologue, as in the imperial era, it is not a full dialogue between equal partners either. While there may not be "giving" and "receiving" courts in the same sense as during the colonial period, the question is whether all courts are in fact beginning to experience a shared commitment to the transjudicial system, or whether old patterns are simply replicating themselves in a division between courts that approve and those that seek approval. ${ }^{21}$

Commentators have suggested not only that the processes of judicial globalization are different from those of the colonial era, but also that the motives for constructing today's global judicial community are new. (Although, as Professor McLean suggests in her description of the Privy Council's role in the colonies,

18. New Zealand Bill of Rights Act, 1990 (N.Z.); see also McLean, supra note *, at 170.

19. For instance, Bahdi distinguishes concern for the rule of law (where the judge feels that the national court is bound to apply an international norm) from interest in the reasoning of foreign courts (where the judge may choose whether to accept or reject the norm). Bahdi, supra note 3 , at $585-89$.

20. See supra note 16.

21. In some respects, a court's awareness of and response to its standing in the global judicial community may yield positive effects. For example, the influence of certain courts as "givers" of international norms may wane if they continue to refrain from the dialogue in which others participate, while the influence of others may rise as they participate actively in transjudicialism in "deliberately seek [ing] to reestablish their place in a global judicial community." See Global Community, supra note 3, at 198; see also Frederick Schauer, The Politics and Incentives of Legal Transplantation, in Governance in a Globalizing World 253, 258-61 (Joseph S. Nye Jr. \& John D. Donahue eds., 2000). 
the motives for imposing external norms on colonial courts were mixed in that era as well: the use of imperial law in colonial courts was intended as a means of protecting the "rights and liberties of British subjects in the colonies," and the common law that it protected had "globalizing aspirations." 22 ) A primary motive behind the introduction of international norms into domestic constitutional decision making today is ensuring basic protections of individual rights around the globe-in part by using the power of national judiciaries to secure fair treatment in each country of local citizens. ${ }^{23}$ Ensuring such basic protections is an unassailable priority, and the validity of processes that bring international human rights norms to bear in national courts rests on the claim of human rights to universality. Even here, though, questions of relative power and authority are presented. Commentators have pointed to the danger of "judicial imperialism" in the mechanisms by which human rights law of Western origin is spread in other countries, ${ }^{24}$ and to local resistance created in part by the use of colonial institutions for that purpose. ${ }^{25}$ Even more problematic is the question of how power and influence will affect transjudicialism outside the human rights field. First, it seems possible that patterns and habits judges develop in one area may transfer to their adjudication in others where the norms in question do not have such a claim to universality. Second, judicial globalization is also simply a variety of globalization of lawyers, and of law, that is largely economic in its origins. ${ }^{26}$ Here, in the economic sphere, the relative status of particular states in the international community-and the power of only some states to generate rather than simply apply the international norms in question-are more clearly reflected in the transjudicial process.

International economic instruments may present less of an immediate formal challenge to New Zealand's system of parliamentary sovereignty than do human rights instruments, due to the way in which they are negotiated and

22. See McLean, supra note *, at 164-65.

23. Indeed, it has been a strategic decision by human rights organizations to use national courts in this way.

24. See Bahdi, supra note 3, at 597-99.

25. See Laurence R. Helfer, Overlegalizing Human Rights: International Relations Theory and the Commonwealth Caribbean Backlash Against Human Rights Regimes, 102 Colum. L. Rev. 1832 (2002).

26. See Judicial Globalization, supra note 3, at 1113 (discussing "a kind of legal globalization that is both cause and consequence of economic globalization"). 
adopted. Nevertheless, Professor McLean notes, they present just as great a challenge to the domestic system in terms of actual impact in their present and future implementation. ${ }^{27}$ Here, in the economic arena, the issues of power underlying the source and implementation of international instruments are inescapable. As Professor McLean points out, the influence of a small country like New Zealand in the negotiation of the treaties whose norms will then be applied domestically is more limited than the influence of a country like the United States. ${ }^{28}$ Thus, although the multilateral process by which such treaties are developed creates at least the potential for small countries to participate in coalitions that might balance the power of larger states, ${ }^{29}$ less powerful countries remain susceptible to the imposition from the outside of a particular vision of economic governancea process that raises echoes of the imposition of imperial law on the colonies. As Professor Hirschl argues elsewhere in this volume, constitutionalization may be used not only to spread human rights but also to preserve hegemonic economic, legal, and social relationships. ${ }^{30}$

Professor McLean's paper provides a view from New Zealand of nationhood in an era of globalization. Asking the hard questions about power and multilateralism and sovereignty that her paper invites is necessary to a fair evaluation of global processes and to the development of the best transjudicial practices possible.

27. McLean identifies, for example, the one-line incorporation of the TRIPs agreement into New Zealand law. McLean, supra note *, at 177.

28. McLean, supra note *, at 176. For a discussion of the relative influence of states in developing TRIPs, see Peter Drahos, Developing Countries and International Intellectual Property Standard-Setting, 5 J. World Intell. Prop. L. 765, 769-70 (2002).

29. McLean, supra note *, at 179.

30. Ran Hirschl, The Political Origins of the New Constitutionalism, 11 Ind. J. Global Legal Stud. 71, 84-86 (2004). 


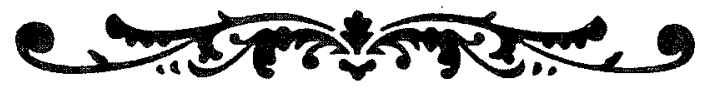

To order a subscription or a single issue of this Journal please call:

1-800-842-6796 or visit our website at:

www.iupjournals.org

200.

Indiana University PREsS 601 North Morton Street

BLOOMINGTON, IN 47404 PHONE: 1-800-842-6796

FAX: $1-812-855-8507$

EMAIL: JOURNALS@INDIANA.EDU WEBSITE: WWW.IUPJOUR NALS.ORG

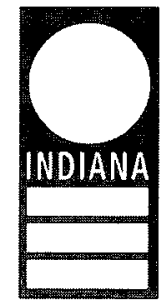

